\begin{tabular}{|l|l|}
\hline $\begin{array}{l}\text { To (Receiving Organization) } \\
\text { Sıte-Wıde SNF Projects }\end{array}$ & $\begin{array}{l}\text { S From (Originatıng Organization) } \\
\text { Site-Wıde SNF Projects }\end{array}$ \\
\hline $\begin{array}{l}5 \text { Proj/Prog/Dept/Div } \\
200 \text { Area Interım Storage Area }\end{array}$ & $\begin{array}{l}\text { 6 Design Authority/Design Agent/Cog Engr } \\
\text { Dale M Johnson }\end{array}$ \\
\hline
\end{tabular}

8 Origınator Remarks

For Approval and Release

\begin{tabular}{|l}
4 Related EDT No \\
N/A \\
\hline 7 Purchase Order No \\
N / A \\
\hline 9 Equip /Component No \\
N/A \\
\hline 10 System/Bidg /Facility \\
212 H \\
\hline 12
\end{tabular}

12 Major Assm Dwg No

13 Permit/Permit Application No $\mathrm{N} / \mathrm{A}$

14 Required Response Date August 24, 1999

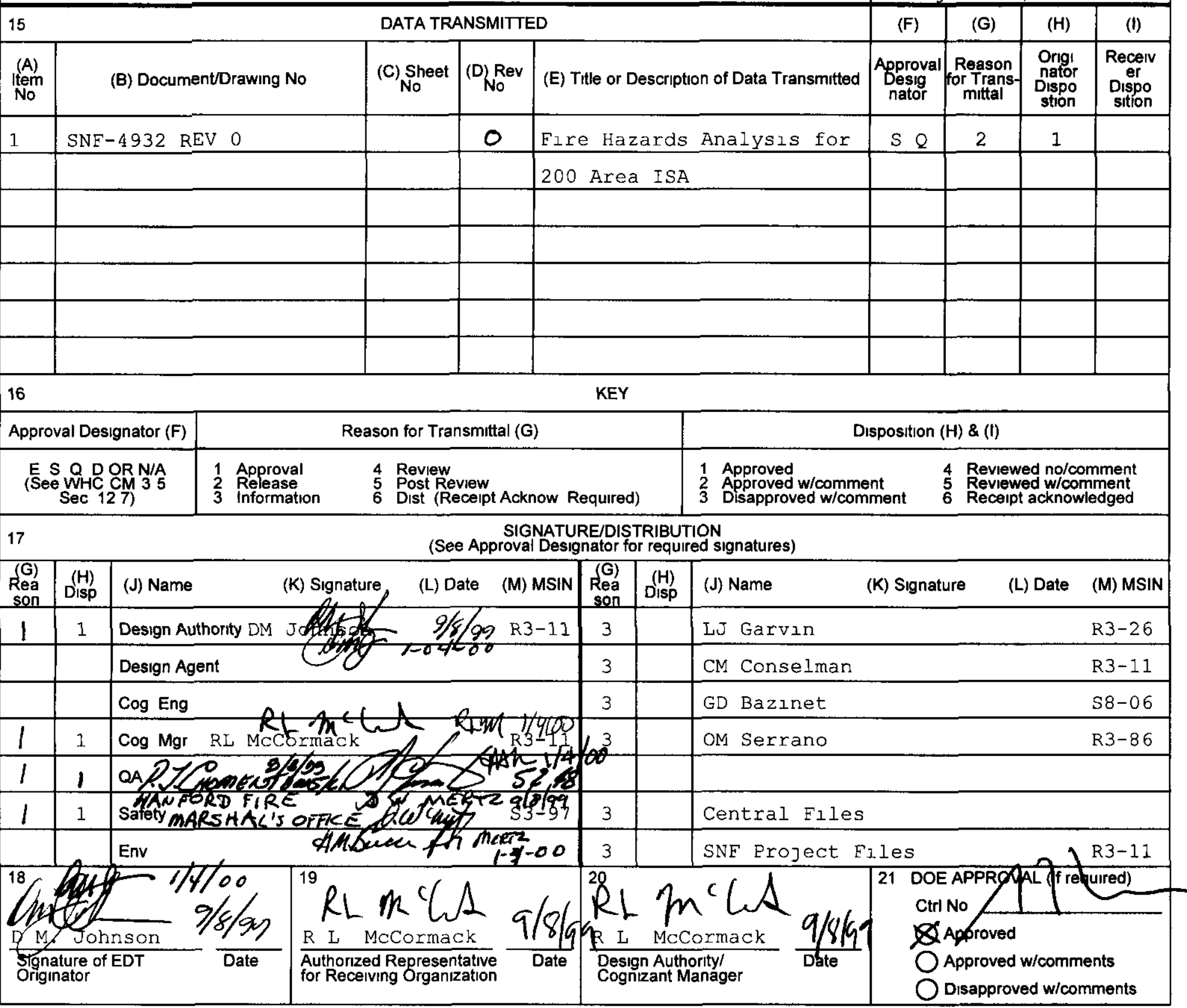




\section{DISTRIBUTION SHEET}

\begin{tabular}{|l|l|}
\hline To & From \\
Distribution & Site-Wide SNE Projects \\
\hline
\end{tabular}

Project Title/Work Order

SNE-4932, Rev 0

Fire Hazards Analysis for 200 Area ISA

\begin{tabular}{|llll}
\hline & & & \\
& & & \\
& & \\
G & D & Baze \\
\hline R & D & Carrell & \\
\hline C & M & Conselman \\
\hline L & J & Garvin & \\
\hline D & M & Johnson & (3 Coples) \\
\hline R & L & McCormack \\
\hline D & W & Mertz \\
\hline M & F & Nicol \\
\hline O & M & Serrano \\
\hline & &
\end{tabular}

SNF-pognt fule
Page 1 of 1

Date $1 / 5 / 00$

EDT No 627772

ECN No N/A

\begin{tabular}{c|c|c|c|}
$\begin{array}{c}\text { Text } \\
\text { With All } \\
\text { Attach }\end{array}$ & Text Only & $\begin{array}{c}\text { Attach / } \\
\text { Appendix } \\
\text { Only }\end{array}$ & $\begin{array}{c}\text { EDT/ECN } \\
\text { Only }\end{array}$ \\
\hline
\end{tabular}

$x$

$x$

$x$

$x$

$x$

$x$

$x$

$x$

$R 3-11$

$x$ 


\title{
Fire Hazards Analysis for the 200 Area Interim Storage Area
}

\author{
D M Johnson
}

Richland WA 99352

U S Department of Energy Contract DE AC06 96RL13200

$\begin{array}{lll}\text { EDT/ECN } & 627772 & \text { UC 2050 } \\ \text { Org Code } & \text { FQ110000 } & \text { Charge Code 41100 } \\ \text { B\&R Code } & \text { EWO4 J1110 } & \text { Total Pages 21 }\end{array}$

Key Words Spent Nuclear Fuel, Interım Storage Cask, NAC-1 Cask, Rad-Vault, 200 Area Interım Storage Area

\begin{abstract}
This documents the Fire Hazards Analysis for the 200 Area Interım Storage Area The Interım Storage Cask, Rad-Vault, and NAC-1 Cask are analyzed for fire hazards and the 200 Area Interım Storage Area Is assessed according to $\mathrm{HNF}-\mathrm{PRO}-350$ and the objectives of DOE Order $54807 \mathrm{~A}$
\end{abstract}

TRADEMARK DISCLAIMER Reference herein to any specific commercial product process or service by trade name trademark manufacturer or otherwise does not necessarily constitute or imply its endorsement recommendation or favoring by the United States Government or any agency thereof or its contractors or subcontractors

Printed in the United States of America To obtain copies of this document contact Document Control Services P O Box 950 Mallstop H6 08 Rıchland WA 99352 Phone (509) 3722420 Fax (509) 376-4989
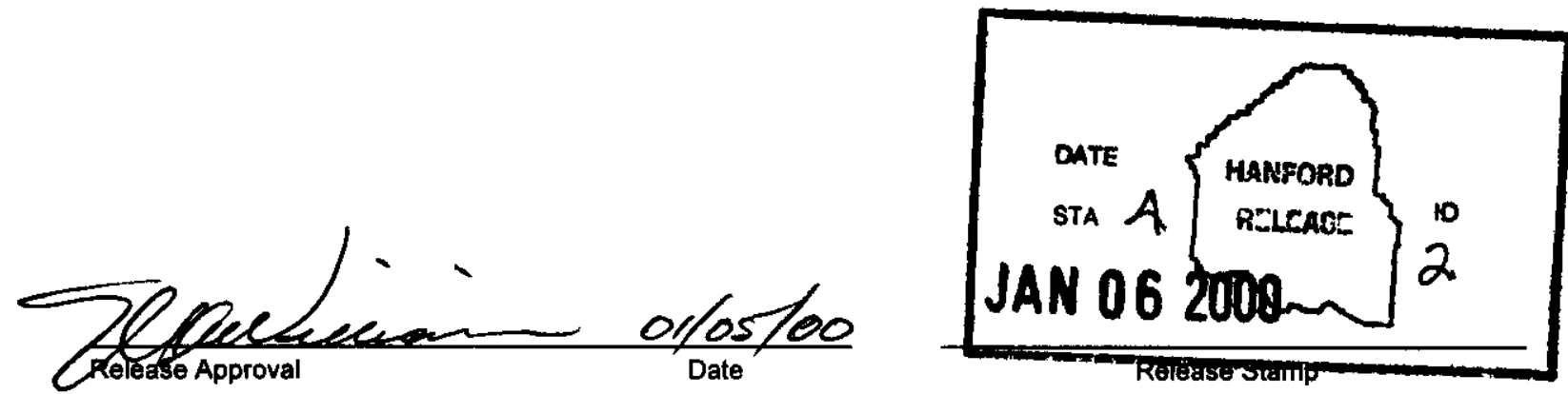

\section{Approved For Publıc Release}


SNF-4932, Rev 0

FIRE HAZARD ANALYSIS

for the

200 EAST AREA INTERIM STORAGE AREA FACILITY

Fluor Danel Hanford

DynCorp Tn-Cities Services, Inc

October 1999

Prepared by

D M Johnson

D W Mertz, PE 
TABLE OF CONTENTS

10 INTRODUCTION

11 Background

12 Purpose

13 Scope

14 Assumptions and Limitations

20 SUMMARY AND CONCLUSIONS

21 Summary

22 Conclusions

30 FACLITY DESCRIPTION

31 ISA Construction

32 Dry Cask Storage Systems

321 Intenm Storage Cask

3211 Physical Description

3212 Compliance with CFR Criteria

322 NAC-1 Cask

3221 Physical Description

3222 Compliance with CFR Criteria

323 Rad-Vault

3231 Physical Description

3232 Complance with CFR Critena

33 Equipment Operation

40 FIRE PROTECTION FEATURES

41 Fire Barners

42 Manual Fire Fighting Equipment

43 Fire Alarm System

44 Portable Fire Extingushers

50 DESCRIPTION OF THE HAZARDS

51 General Description

4

52 Summary of CFR Critena 10

53 Fire Hazards 10

54 Fure Analyses 11

541 Liquid Fuel Fire 11

542 Combination Liquid Fuel and Plywood Fire 12

543 Fuel Truck 13

544 Conclusion 14

60 SAFETY SYSTEMS, STRUCTURES AND COMPONENTS (SSC)

$\begin{array}{lll}70 & \text { LIFE SAFETY CONSIDERATION } & 15\end{array}$

80 CRITICAL PROCESS EQUIPMENT 15

90 HIGH VALUE PROPERTY 15

100 DAMAGE POTENTIAL 16

110 FIRE DEPARTMENT RESPONSE 16

120 RECOVERY POTENTIAL 16 
130 POTENTIAL FOR A TOXILOGICAL, BIOLOGICAL AND/OR RADIOLOGICAL INCIDENT DUE TO A FIRE 16

$\begin{array}{lll}140 & \text { EMERGENCY PLANNING } & 17\end{array}$

150 SECURITY AND SAFEGUARDS CONSIDERATIONS RELATED TO FIRE PROTECTION

160 NATURAL HAZARDS IMPACT ON FIRE SAFETY

170 EXPOSURE FIRE POTENTIALS, INCLUDING THE POTENTIAI FIRE SPREAD BETWEEN FIRE AREAS

$\begin{array}{lll}180 & \text { RECOMMENDATIONS } & 18\end{array}$

$\begin{array}{llr}190 & \text { REFERENCES } & 19\end{array}$ 


\section{INTRODUCTION}

This Fire Hazards Analysıs (FHA) addresses the 200 East Area Interım Storage Area (ISA) facility The ISA facility is located to the West of the Canister Storage Bullding (CSB) and provides for the interım storage of non-defense production reactor Spent Nuclear Fuel (SNF) The SNF will be housed in three separate dry cask storage systems The ISA facility includes concrete storage pads to support the dry cask storage systems and is enciosed within perımeter fencing

\section{Background}

The ISA will be use to store SNF from the Fast Flux Test Facility (FFTF), the 324 Bullding and the Neutron Radiography Facility (NRF) Each facility has a different dry cask storage system The three dry cask storage systems being placed at the 200 Area ISA are the Interım Storage Cask (ISC), which is used for the Fast Flux Test Facility (FFTF) SNF, the NAC-1 cask housed within International Standards Organization (ISO) containers used for the 324 SNF and the Rad-Vault ${ }^{T M}$ which is used to store Test Reactor and Isotope Production General Atomics (TRIGA ${ }^{\otimes 1}$ ) casks and U S Department of Transportation (DOT)-6M containers filled with SNF from the NRF The dry cask storage systems are designed for a life of 40 years Interim storage is intended at the ISA untıl the materials are shipped to a disposal facility

The ISCs, NAC-1 casks, Rad-Vault ${ }^{\mathrm{TM}}$ and NRF TRIGA ${ }^{\circ}$ casks have been analyzed to meet the radioactive material release criteria of Title 10, Code of Federal Regulations (10 CFR) Section 71 51(a)(2) from exposure to the 10 CFR Section $7173(\mathrm{c})(4)$ thermal exposure conditions

\section{Purpose}

This FHA addresses the potential fire hazards associated with the ISA facility in accordance with the requirements of DOE Order $54807 \mathrm{~A}$ it is intended to assess the risk from fire to ensure there are no undue fire hazards to site personnel and the public and to ensure property damage potential from fire is within acceptable limits This FHA will be in the form of a graded approach commensurate with the complexity of the structure or area and the associated fire hazards

The FHA evaluates the ISA facility to ascertain whether the objectives of DOE Order $54807 \mathrm{~A}$, Fire Protection are met These objectives are as follows

- Minımize the potential for the occurrence of a fire

- Ensure that the fire does not cause an on-site of off-site release of radiological and other hazardous material that will threaten public health and safety or the environment

- Ensure that an acceptable degree of life safety to DOE and contractor personnel is provided 
- Ensure that vital DOE programs will not suffer unacceptable delays as a result of fire and it effects

- Ensure property damage from a fire does not exceed an acceptable level

\section{Scope}

This FHA was prepared in accordance with DOE $54807 \mathrm{~A}$, Fire Protection, and HNFPRO-350 Rev 2, Fire Hazard Analysis Requirements The FHA evaluates the potential fire hazards scenarios associated with the ISA and the potential consequences should any of the scenarios occur The scenarios are evaluated using the 10 CFR 7173 thermal exposure as a baseline to determine if they are bounded by the 10 CFR 7173 thermal exposure criteria The fire hazards described in this report and the potential affects to the dry cask storage systems include

- Fire involving solid combustıble materials such as plywood, cardboard, pallets, etc

- Vegetation fire

- Fire involving a combination of liquid fuel and solid combustıble materials

- Liquid fuel fire

\section{Assumptions and limitations}

Each of the three dry cask storage systems have been determıned through analysı (GA 1995 for ISC, NAC 1990 and TRI 1996 for NAC-1 Cask and WHC 1995 for RadVault) to meet the thermal exposure criteria established in 10 CFR 7173 The determination as to whether the selected fire scenarıos are bounded by the $10 \mathrm{CFR}$ 7173 exposure criteria is dependent on the use of accurate modeling of the dry cask storage systems in concluding that the storage systems meet the 10 CFR 7173 exposure criteria The assumption is made in this FHA that the modeling for each of the dry cask storage systems is accurate

\section{SUMMARY AND CONCLUSIONS}

\section{Summary}

This report evaluated the fire hazards and life safety associated with the maintenance and operation of the ISA faclity The report also assessed the damage potential in terms of dollar value with regard to a fire involving a dry storage cask system

\section{Conclusions}

- A fire involving diesel fuel from both the crane and tractor/transporter is bounded by the 10 CFR 7173 thermal analysis criteria

- The crane and tractor/transporter may be operated without fuel restrictions within the ISA facility

- The impact to the dry cask storage systems from a fire that exceeds the $10 \mathrm{CFR}$ 7173 criteria is unknown Therefore the fuel truck must remain outside the ISA perımeter fencing at all tımes Transporter tractor truck and the crane refueling operations must take place outside the perımeter fencing A fire involving 
combustible materials such as dimensional lumber, cardboard, plastic, etc is bounded by the liquid fuel fire provided the quantity of these materials is limited to an equivalent of two, stacked $3 / 4^{n}$, sheets of plywood over a $32 \mathrm{ft}^{2}$ area

- Plywood, $3 / 4$ ' in thickness may remain on the concrete storage pads in any quantity provided it is stacked no more than two sheets high and no additional combustibles are placed on the stacked plywood

- The ISA facility meets the DOE 5480 7A fire protection criteria without fire suppression systems provided the recommendations identified in section 180 of this report are resolved and implemented

\section{FACILITY DESCRIPTION}

\section{ISA Construction}

The 200 Area ISA facility is located west of the Canister Storage Bulding (CSB), $212 \mathrm{HW}$ (see figure 1) The ISA footprint is approximately 500 feet by 400 feet and is surrounded by an 8 foot tall chain link fence Gates in the fence allow access and egress of vehicles and personnel into and out of the ISA Light poles around the perimeter provide lliumination Concrete pads within the ISA perimeter will be used for placing the ISC's and the NAC-1 casks within the ISO containers The Rad-Vault holding the NRF TRIGA casks and the DOT-6M containers will be placed on a compacted gravel pad

\section{Dry Cask Storage Systems}

The 200 Area ISA, ISCs, Rad-Vault ${ }^{\mathrm{TM}}$ and NRF TRIGA ${ }^{\star}$ casks, and ISO contaners are constructed of non-combustible materials The DOT-6M containers have an impact absorber (located at the bottom of the cask) and a spacer (located near the top) that is constructed of fire retardant plywood The sIX NAC-1 casks have impact limiters at both ends that are made of balsa wood and asbestos sheathed withın stainless steel These combustibles were taken into account in the Rad-Vault ${ }^{\mathrm{TM}}$ and NAC-1 cask analyses

\section{Interim Storage Cask}

\section{Physical Description}

The ISC contains SNF from the FFTF The ISC contains up to seven spent fuel components which have been placed within a Core Component Container (CCC) following removal from sodium storage withın the reactor bulling and washing The ISC is a right circular cylinder with an inner steel confinement structure surrounded by reinforced concrete The ISC is nominally 15 feet tall and 7 feet in diameter, weighing 115,000 pounds Up to 60 ISCs could potentially be stored at the 200 Area ISA 


\section{AREA ISA SITE PLAN \\ (Draw/ng \# H 2-829740)}

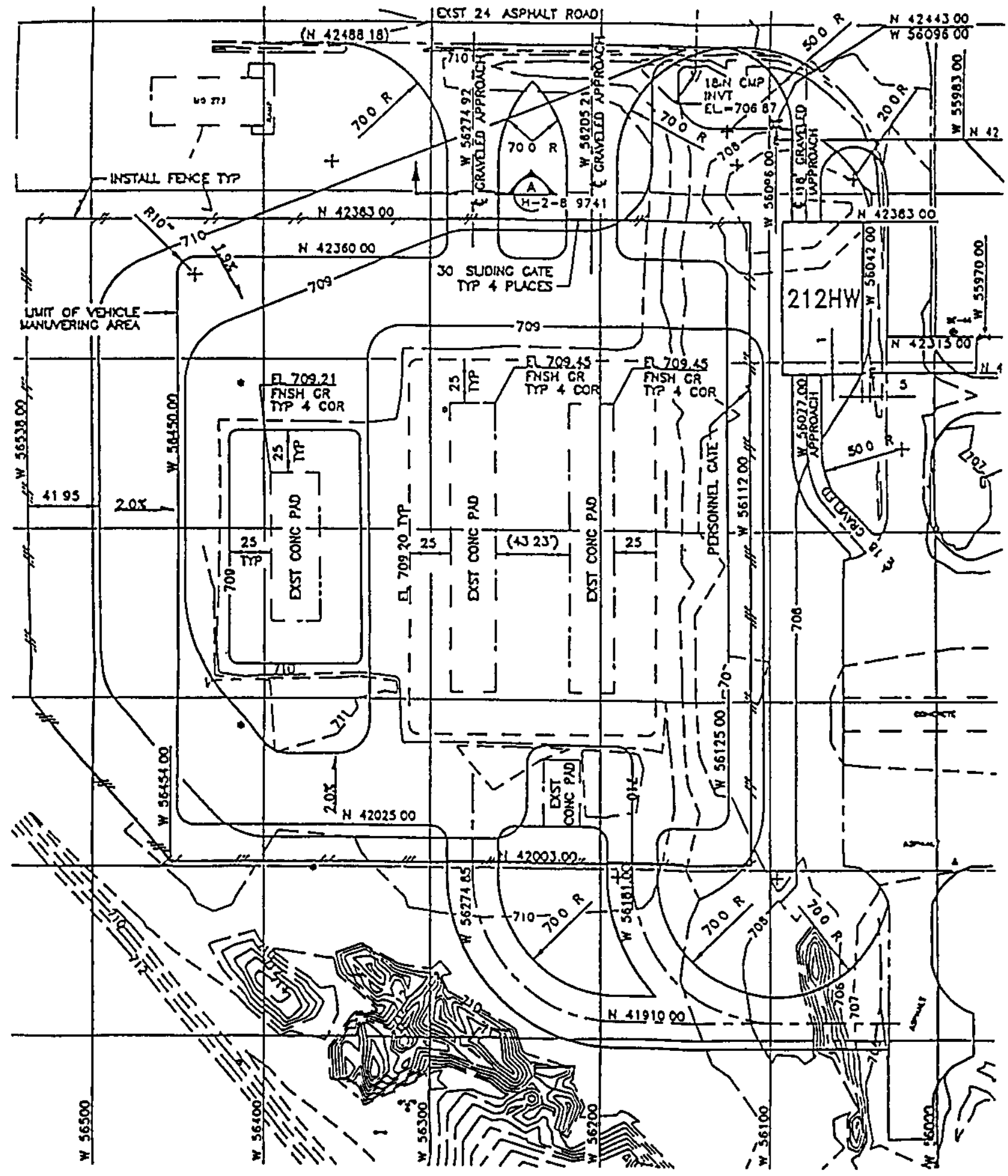

Figure 1 


\section{Compliance with CFR criteria}

The ISC was analyzed by General Atomic to the transient fire accident criteria for transportation as defined above (GA 1995) Following the 30 minutes of exposure to the fire, the ambient environment returns to normal temperature, but no artficial cooling is assumed For this short-term thermal loading to the ISC, it was determined that the amount of concrete remaining below the $\mathrm{ACl}-349$ accident condition limit of $177^{\circ} \mathrm{C}$ $\left(350^{\circ} \mathrm{F}\right)$ was more than adequate to meet the shielding criteria of $1 \mathrm{rem} / \mathrm{hour}$ at 1 meter Additionally, the fire produced negligible increase in stress and resulted in acceptable temperatures of the all-metal components of the confinement boundary The ISC radioacitve payload was determined to be unaffected following exposure to the $10 \mathrm{CFR}$ 7173 (c)(4) thermal exposure

\section{NAC-1 Cask}

\section{Physical Descnption}

ISO containers are used to house NAC-1 casks that contain the commercial light water reactor (LWR) SNF currently at the 324 Building in the Hanford Site 300 Area Within each NAC-1 cask will be an inner container, which will provide confinement for the LWR SNF Each inner container will hold either an individual assembly or consolidated rods The NAC-1 cask is a metal cask, which provides structural strength and shielding for the inner canister Each NAC-1 cask is approximated by a right circular cylinder 214 inches long, which has a maximum diameter of 50 inches Loaded gross weight of the cask is approximately 49,000 pounds Each NAC-1 cask is placed in an ISO container which provides weather protection Each ISO container footprint is 8 feet by 20 feet Six $1 S O$ containers will be initially stored at the 200 Area ISA

\section{Compliance with CFR Critena}

The NAC-1 cask was previously analyzed for the transportation fire scenario in the NAC-1 safety analysis report (SAR) (NAC 1990 and TRI 1996) for a 750 watt internal thermal load, which is greater than the thermal load of the inventory to be stored The analysis demonstrated the NAC-1 cask maintains its integrity and meets the 10CFR Section $7151(a)(2)$ limits during the 10CFR Section $7173(\mathrm{c})(4)$ fire conditions Exposure temperatures will not cause cavity and seal temperatures or pressure design IImits to be exceeded Additionally, the shielding is expected to be maintained at an acceptable level There would be no loss of confinement durıng the fire and the canister will retain its integrity to protect the SNF

\section{Rad-Vault}

\section{Physical Description}

A Rad-Vault ${ }^{T M}$ is used to store and DOT-6M containers which hold TRIGA ${ }^{\star}$ SNF from the Neutron Radıography Facility in the 300 Area Each NRF TRIGA ${ }^{\oplus}$ cask, holdıng up 
to 17 elements, is nominally 38 inches tall and 16 inches in diameter Each DOT-6M container, holding one element in an inner $2 R$ container, is nominally 70 inches tall and 23 inches in diameter The Rad-Vault ${ }^{\mathrm{TM}}$ is a concrete right circular cylinder with light steel reinforcement The empty Rad-Vault ${ }^{\mathrm{TM}}$ weighs 63,400 pounds, consisting of the 43,400 pound body and 20,000 pound lid The loaded weight of the storage system is 76,760 pounds With the lid installed the Rad-Vault ${ }^{\mathrm{TM}}$ is 111 inches high with an outer diameter of 114 inches A similar storage arrangement consisting of NRF TRIGA casks within a Rad-Vault ${ }^{\mathrm{TM}}$ may be employed for TRIGA ${ }^{\oplus}$ SNF currently at the 200 West Area Low Level Burial Grounds

\section{Compliance with CFR Criteria}

The Rad-Vault ${ }^{\mathrm{TM}}$ was analyzed and determıned to meet the 10CFR Section 71 51(a)(2) radioactive material release criteria The TRIGA fuel cladding emperature limit of $149^{\circ} \mathrm{C}\left(302^{\circ} \mathrm{F}\right)$ would not be exceeded although the design specification for concrete temperature exposure for the Rad-Vault ${ }^{\top \mathrm{m}}$ could be exceeded for a short period from exposure to the fire conditions

It has been determined no radıological release would result from exposure of the RadVault $^{\mathrm{TM}}$ to the 10CFR Section 7173 (c)(4) fire Exposure temperatures will not cause cavity and seal temperatures or pressure design limits to be exceeded The NRF TRIGA ${ }^{7}$ casks and DOT-6M containers will be delivered to the 200 Area ISA and placed Into the Rad-Vault ${ }^{\mathrm{TM}}$

\section{EQUIPMENT OPERATION}

Equipment operated at the 200 Area ISA facility includes the tractor/transporter used for Individual on-site transfer of an ISC, ISO, or Rad-Vault ${ }^{\mathrm{TM}}$ container with their respective payloads The transporter has access to locations near the storage area so that an onsite crawler-crane can make the lift directly from the transporter to the storage location Access-ways allow the crane to be positioned without having to drive onto or over the concrete pads Plywood, commonly used to protect concrete from vehicular traffic, is not required for normal operations in the 200 Area ISA Therefore plywood used for this purpose will not contribute to the combustible loading withın the ISA The cranes that may be used in the ISA are limited to the $\mathbf{2 5 0}$ ton Manatowac $\mathbf{4 6 0 0}$ or the 150 ton Manatowac 4100 The transporter and crane will be operated during initial placement of the dry cask storage systems, future new receipts such as the TRIGA ${ }^{\oplus}$ SNF from the 200 West Area, and future off-loading for transfer to the proposed National Repository The crane will be used for regular periodic inspections and maintenance on the ISCs and TRIGA ${ }^{\oplus}$ casks

\section{FIRE PROTECTION FEATURES}

\section{Fire Barriers}

The ISA facility is located outdoors There are no solid walls or doors associated with this facility As such, there are no fire barners or doors and none are required 


\section{Manual Fire Fightıng Equipment}

There are four fire hydrants that can be used for fighting a fire in or around the ISA facility Hydrant FWX-044 is located approximately 150 feet South of the 200 Area ISA fence line, FWX-045 is located just outside of the southwest fence line, FWX-046 is located approxımately 100 feet from the Northwest corner of the fence line, and FWX047 is located approximately 100 feet North of the fence line

\section{Fire Alarm System}

The 200 Area ISA does not have a fire alarm system and none is required During periods when the risk of fire is heightened by activities within the ISA facility including crane activities, workers with two-way communication resources will be on the site CSB Operations will be responsible for the 200 Area ISA facility and will periodically monitor the ISA when unoccupied and will respond to unusual events at the ISA, Including fire

\section{Portable Fire Extınguishers}

Portable fire extınguishers will not be provided at the ISA The ISA will be routınely inspected to ensure it is kept free of debris and natural vegetation The ISA will also be checked for accumulations of combustibles following windstorms The perimeter fence is expected to keep most of the transient debris away from the dry cask storage systems Housekeeping procedures will be used for the routine inspections and will require notification for removal of accumulated combustibles when necessary

\section{DESCRIPTION OF FIRE HAZARDS}

\section{General Description}

There are no ignition sources or inherent fire hazards associated with the ISCs, RadVault $^{\mathrm{TM}}$ and NRF TRIGA ${ }^{\circ}$ casks, or NAC-1 casks and ISO containers However diesel fuel and/or gasoline powered vehicles are needed to facilitate movement of the ISCs, NRF TRIGA ${ }^{\oplus}$ casks and DOT-6M contaner, and NAC-1 casks and ISO containers into, out of and withın the ISA facility A transporter tractor truck carrying up to 200 gallons of fuel oll will be used to move the casks into and out of the ISA facility A crane carrying up to 100 gallons of fuel oll will be used to move the casks to and from the truck and manipulate them inside the ISA facility It is also anticipated that a tanker truck carrying up to 2500 gallons of gasoline and 500 gallons of fuel oll will be needed periodically to refuel the tractor transporter truck and the crane These vehicles are all potential fire sources

Other potential fire sources in the 200 Area ISA, consist of plywood, cribbing, wooden boxes, pallets, cardboard, paint, plastic tarps, etc Another potential source of combustibles is the accumulation of local vegetation following a windstorm 
The Rad-Vault ${ }^{\mathrm{TM}}$ sits directly on gravel rather than a concrete pad None of the concrete pads or the area around the Rad-Vault ${ }^{\mathrm{TM}}$ are bermed but are surrounded by compacted crushed rock at the same elevation No physical appurtenance would limit a spill from spreading out near the dry cask storage systems

\section{Summary of CFR Cntena}

The ISC's, NAC-1 casks, Rad-Vault ${ }^{\mathrm{TM}}$ and NRF TRIGA casks have been analyzed to meet the radioactive material release criteria of Title 10 CFR Section 71 51(a)(2) from exposure to the 10 CFR $7173(c)(4)$ thermal conditions

The 10 CFR 7151 release criteria limit escape of ${ }^{85} \mathrm{Kr}$ to 10,000 curies in one week The CFR also limits the escape of other radioactive material to less than A2 amount in one week, and limits external radiatıon dose rate to one rem per hour at one meter from the external surface of the package

The 10CFR Section $7173(\mathrm{C})(4)$ thermal conditions are adopted from the requirements established by the International Atomic Energy Agency (IAEA) for the thermal test for demonstrating the ability of the specimen being transported to withstand accident conditions The approaches are specified in the IAEA Safety Standards, Safety Series No 6, Regulations for the Safe Transport of Radioactive Material, and Safety Series No 37, Advisory Material for the IAEA Regulations for the Safe Transport of Radioactive Material The test calls for fully engulfed exposure of the whole specimen for a period of 30 minutes to a hydrocarbon fuel/air fire that provides an average emmisivity coefficient of at least 09 , with an average flame temperature of at least $800^{\circ} \mathrm{C}$ The practical test method described in Safety Series No 37 has the test specimen positioned 1 meter above the surface of the liquid fuel source pool, which extends between 1 and 3 meters beyond the edges of the specimen All sides of the specimen must be exposed to a luminous flame not less than 07 meter and not more than 3 meters thick The fuel is specified to be a distillate of petroleum with a distillation end point of $330^{\circ} \mathrm{C}$ maximum and an open cup flash point of $46^{\circ} \mathrm{C}$ mınımum and a gross heatıng value of between 46 and 49 megajoule/kılogram This covers most hydrocarbons derived from petroleum with a density of less than $820 \mathrm{~kg} / \mathrm{m}^{3}$, e g kerosene and JP4-type fuels

\section{Fire Hazards}

The purpose for the evaluation of the fire scenarios identified in this FHA is to determine If the scenarios are bounded by the 10 CFR 7173 analysis Those scenarios which are bounded will require no controls either engineered or adminıstrative Those scenarios which are not bounded will require engineered or administratıve controls to reduce the severity of the accident or elımınate the hazard

The worst case fire for any of the dry cask storage systems is one that fully engulfs the cask The most likely way for this to occur would be a liquid fuel spill underneath the cask that is somehow ignited Fires involving solid materials could result in exposure to the cask but full engulfment is unlikely at the heat flux required by the 10 CFR71 73 
criteria Liquid fuels such as fuel oll and gasoline have heats of combustion up to twice those of most types of wood The contribution of combustible materials such as dimensional lumber, plywood, etc in combination with a liquid fuel are not likely to have a significant impact to the severity of a fire engulfing a cask However, this scenarıo was evaluated in section 542

The liquid fuel fire is the most likely and potentially the most significant fire event for the ISA facility Liquid fuel leaking from the transporter truck, the crane or the fuel truck could result in a fire that engulfs any one of the dry cask storage systems Fuel leaks could be either of two ways A catastrophic fallure of a fuel tank would cause all the fuel to leak almost instantaneously However, the most conservatıve and likely scenarıo would be a constant leakage rate from one of the vehicles The worst case scenarıo would be that in which the leakage rate of fuel from the vehicle was equal to the burn rate of the fuel pool fire at the required pool diameter for a particular item as established In 10 CFR 7173

The footprints of the three dry cask storage systems are as follows

- ISC -7 foot $(213 \mathrm{~m})$ diameter $\left(384 \mathrm{ft}^{2}\right)\left(358 \mathrm{~m}^{2}\right)$

- ISO Container -8 feet $(243 \mathrm{~m})$ by 20 feet $(61 \mathrm{~m})\left(160 \mathrm{ft}^{2}\right)\left(149 \mathrm{~m}^{2}\right)$

- Rad-Vault ${ }^{T M}-114$ inch $(29 \mathrm{~m})$ diameter $\left(7089 \mathrm{ft}^{2}\right)\left(659 \mathrm{~m}^{2}\right)$

\section{Fire Analysis}

\section{Liquid Fuel Fıre}

The ISC footprint encompasses the smallest area This will result in the smallest burn rate and therefore the smallest leakage rate that is required to produce the minımum pool diameter for compliance with the 10 CFR 7173 test criteria With the leakage rate equal to the burn rate for a period of 30 minutes, the smallest quantity of fuel needed to produce a fire equivalent to the $10 \mathrm{CFR} 7173$ fire can be determined If the quantity of fuel at the ISA facility is limited to this amount, a fuel fire involving any of the dry cask storage systems will not be more severe than the 10 CFR 7173 thermal analysis test This quantity of fuel will be enough to engulf the ISC container per the 10 CFR 7173 criteria but will not be enough to engulf the ISO Container or the Rad-Vault ${ }^{\mathrm{TM}}$ cask systems per the 10 CFR 7173 critena

The burn rate or mass loss rate of the fuel oll must be known for the chosen diameter in order to determıne how much fuel will burn in 30 minutes The fuel mass loss rate, $M^{n}$, has been shown by [Babrauskas, 1993] to be relatively constant for equivalent hquid fuel pool diameters, $d$, greater than $1 \mathrm{~m}$ The 10 CFR 7173 test criteria requires that the fuel extend at least 1 meter but not more than $3 \mathrm{~m}$ beyond any external surface of the specimen Using the ISC as a specimen, the minımum pool diameter, $d$, is $213 \mathrm{~m}$ + $200 \mathrm{~m}=413 \mathrm{~m}$ The characteristics of diesel fuel are closely approximated to those of kerosene The pertınent characterıstıcs given by Babrauskas [1993] for kerosene are as follows

Density, D $=820 \mathrm{~kg} / \mathrm{m}^{3}$ 
Fuel Mass Loss Rate, $M^{n}=039 \mathrm{~kg} / \mathrm{m}^{2}-\mathrm{s}$

Additional variables and standard conversions are as follows

Time, $\mathrm{t}=1800 \mathrm{sec}$ (30 minutes)

Diameter, $d=413 \mathrm{~m}$

Area, $A$, calculated from diameter $=134 \mathrm{~m}^{2}$

1 gallon $=0003785 \mathrm{~m}^{3}$

Volume, $\mathrm{V}=$ ?

Calculate the volume burned in a $\mathbf{3 0}$ minute period as follows

$V=\left(M^{\prime \prime}\right)(A)(t) / D$

$V=\left(039 \mathrm{~kg} / \mathrm{m}^{2}-\mathrm{s}\right)\left(134 \mathrm{~m}^{2}\right)(1800 \mathrm{~s}) / 820 \mathrm{~kg} / \mathrm{m}^{3}=115 \mathrm{~m}^{3}$

$V=\left(115 \mathrm{~m}^{3}\right)\left(1\right.$ gallon $/ 0003785 \mathrm{~m}^{3}=304$ gallons

If the maximum pool diameter per the 10 CFR 7173 criteria were used then the quantity of fuel burned in a 30 minute period would be as follows

$d=213 m+6 m=813 m$

$A=519 \mathrm{~m}^{2}$

$V=\left(0039 \mathrm{~kg} / \mathrm{m}^{2}-\mathrm{s}\right)\left(519 \mathrm{~m}^{2}\right)(1800 \mathrm{~s}) / 820 \mathrm{~kg} / \mathrm{m}^{3}=44 \mathrm{~m}^{3}$

$V=\left(44 \mathrm{~m}^{3}\right)\left(1\right.$ gallon $\left./ 0003785 \mathrm{~m}^{3}\right)=1173$ gallons

\section{Combınatıon Liquid Fuel and Plywood Fire}

The possibility exists that combustible materials, plywood for example, in combination with fuel oll could be involved in fire within the cask boundaries established by the 10 CFR 7173 thermal analysis criteria Fuel oll has a higher heat of combustion than ordinary combustıbles such as wood, paper, cloth, etc and most plastics Therefore, if the burn tıme of the plywood is minımized to not more than 30 mınutes, then the impact of the burning plywood will be bounded by the liquid fuel fire This analysis will determine how many stacked sheets of plywood will produce a burn tıme of $\mathbf{3 0}$ minutes or less

Two, stacked, $3 / 4$ sheets of plywood laying flat are analyzed for burn tıme as follows

Average burn rate for wood, $M^{n}=257 \mathrm{E}-2 \mathrm{lb} / \mathrm{m}^{2} \mathrm{~s}$

Heat of Combustion for wood, $h_{c}=8000$ BTU/lb

Area, $A=4 \mathrm{ft} \times 8 \mathrm{ft}=32 \mathrm{ft}^{2}=3 \mathrm{~m}^{2}$

Heat Release Rate, $q^{n}=\left(M^{n}\right)\left(h_{c}\right)(A)=\left(286 E-2 \mathrm{lb} / \mathrm{m}^{2} \mathrm{~s}\right)(8000 \mathrm{BTU} / \mathrm{lb})\left(3 \mathrm{~m}^{2}\right)=686 \mathrm{BTU} / \mathrm{s}$

The total heat produced by one sheet of plywood is as follows 
Volume $V$ of one sheet of plywood is $(4 \mathrm{ft})(8 \mathrm{ft})(00625 \mathrm{ft})=2 \mathrm{ft}^{3}$

Density, $D$, of plywood $=35 \mathrm{lb} / \mathrm{ft}^{3}$

Total weight, $W$, of one sheet of plywood is

$W=(V)(D)=\left(2 \mathrm{ft}^{3}\right)\left(35 \mathrm{lb} / \mathrm{ft}^{3}\right)=70 \mathrm{lb}$

$H=(W)\left(h_{c}\right)=(70 \mathrm{lb})(8000 \mathrm{BTU} / \mathrm{lb})=560,000 \mathrm{BTU} / \mathrm{sheet}$

The total time, $t$, to burn one sheet under ideal conditions is

$t=(560,000 \mathrm{BTU} /$ sheet $) / 686 \mathrm{BTU} / \mathrm{s})=816 \mathrm{~s} / \mathrm{sheet}$

The time to burn both sheets is

$t=816 \mathrm{~s} / \mathrm{sheet}(2$ sheets $)=1632 \mathrm{~s}=27$ minutes

The limit on the number of sheets plywood that can be stacked is two An equal or lesser amount of combustible material equivalent to that of two sheets of plywood over a $32 \mathrm{ft}^{2}$ is also permitted The total number of sheets of plywood on each storage pad is not limited as long as they are stacked no more than two sheets high

\section{Fuel Truck}

The fuel truck could be carrying up to 2500 gallons of gasoline and 500 gallons of fuel oll This quantity of fuel could potentially subject the dry cask storage systems to a fire that is outside the bounds of the 10 CFR 7173 fire test criteria

The "principles" of NFPA 30, Flammable and Combustible Liquids Code, 1996 edition, were used to establish that the separation distances afforded by keeping the fuel truck outside the perımeter fencing at all times are adequate to protect the dry cask storage systems from an exposure fire due to spilled fuel from the fuel truck. Section 2-3 42 of NFPA 30 describes the spill control protection method of remote impounding Remote impounding is a method in which spilled liquid is routed or drained to a remote area The Flammable and Combustible Liquids Codes Handbook states in the commentary for this section that the impounding area must be located so that, if the spill ignites, the fire will not serıously damage other tanks or adjoınıng property This distance is established in Section 2-3 42 (d) which states in part, "The confines of the impounding area shall be located so that, when filled to capacity, the liquid level will not be closer than $50 \mathrm{ft}(15 \mathrm{~m})$ from any property line that is or can be bult upon, or from any tank"

The location of ISA perimeter fencing is shown in Figure 1 Access to the ISA is from a paved road along the full length of the North side The paving continues the length of the east side of the ISA and for approximately 200 feet along the south side from the east No paved areas are planned for the remainder of the south side of the ISA or the west side The minımum distance from the perımeter fencing to the nearest edge of a 
concrete storage pad is on the East side of the ISA This distance is approximately 80 feet The ground on the East side of the ISA slopes away from the storage pad and towards the perimeter fencing Fuel spilled on the eastern side of the ISA would remain outside the perımeter fencing The perımeter fencing on both the north and south sides of the ISA is approximately 110 feet to the nearest edge of a concrete storage pad The perimeter fencing on the west side is located approxımately 140 feet from the nearest edge of a concrete storage pad The ground on the north, south and west sides of the ISA will be contoured to a slope of approximately $2 \%$ towards the concrete storage pads The slope will begin approxımately at the perımeter fencing boundary A fuel spıll outside the perimeter fencing on the either the north, south or west sides of the ISA will not flow towards the concrete storage pads unless the fuel gets inside the perımeter fencing This could occur due to a large spill in a short amount of time while the truck was parked next to the perımeter fencing or from a pressurized spray leak directed inside the perimeter fencing All ground inside the perımeter fencing with the exception of the concrete pads will be covered with gravel The graveled surface will tend to impede the flow of liquid spills and result in more fuel being absorbed into the ground

Although a specific remote impounding area has not been established for the fuel truck, the increased separation distances and physical configuration of the area between the dry cask storage systems and the fuel truck are considered to meet the intent of NFPA 30 for adequate exposure protection

\section{Conclusion}

- Limiting the diesel fuel to $\mathbf{3 0 4}$ gallons within the ISA fenced area will ensure that the criteria established by the 10 CFR 7173 thermal test are not exceeded for any of the dry cask storage systems

- The tractor and crane carry a combıned maxımum of 300 gallons of diesel fuel, therefore there are no fuel restrictions regarding the use of these vehicles in proximity to any of the dry cask storage systems

- The impact to any of the dry cask systems is unknown if exposed to a fire that exceeds the 10 CFR 7173 thermal test criteria Therefore, the fuel truck must remain outside the ISA perımeter fencing at all times Transporter tractor truck and crane refuelıng operations must take place outside the perimeter fencing The separation distances created between the fuel truck and the dry cask storage system locations by requiring the fuel truck to remain outside the perimeter fencing meet the intent of NFPA 30 for property protection and provide assurance that the dry cask storage systems will not be subjected to a fuel fire that exceeds the $10 \mathrm{CFR}$ 7173 criteria from a fuel truck fuel spill

- Plywood cannot subject the dry cask storage systems to a fire that exceeds the 10 CFR 7173 thermal test criteria provided it is not stacked more than two sheets high and no additional combustibles are placed on the plywood

- The fuel package size of other ordinary combustıbles used on the ISA facilty should be limited to the equivalent of two stacked $3 / 4^{n}$ sheets of plywood over a $32 \mathrm{ft}^{2}$ area 
- The ISA facility meets the DOE $54807 \mathrm{7A}$ fire protection criteria without fire suppression systems provided the recommendations identified in section 180 of this report are resolved and implemented

\section{SAFETY SYSTEMS, STRUCTURES AND COMPONENTS (SSC)}

Safety class structures, systems and components (SSC's) are defined as those engineered safety features that prevent or mitigate accidents resulting in unacceptable consequences to the public on onsite workers The safety classification system follows a graded approach using Safety Class, Safety Significant and General Service designations as defined in the Hazard and Accident Analysis Process (HNF-PRO-704) The 200 Area ISA (excluding the dry cask storage systems) is classified as general service The ISC is designated as safety significant The Rad-Vault ${ }^{\text {TM }}$, NRF TRIGA ${ }^{\oplus}$ casks, and DOT-6M containers are also designated safety significant The canisters within the NAC-1 casks are desıgnated safety significant for confinement and are designated safety class for criticality control The NAC-1 casks are designated safety significant for protection of the canisters, including protection against fire and the ISO containers are classified as general service The bases for these classifications are detalled in Annex D of the SNF Project FSAR, HNF 3553 The transporter and crane are also classified as general service

\section{LIFE SAFETY CONSIDERATIONS}

The ISA facility does not fall into any of the classification categories defined in NFPA 101, Life Safety Code However, the facility has been evaluated for basic life safety criteria The 200 Area ISA is normally unoccupied Personnel access is required during cask transfer operations and periodic survellance and maintenance The gates to the 200 Area ISA shall remain unlocked during occupancy Access to the ISA Is controlled There are a total of four gates to the ISA Two are located at the North end of the site and two at the South end Travel distance to any exit for someone standing in the middle of the site is approxımately 300 feet

\section{CRITICAL PROCESS EQUIPMENT}

The facility does not contain any critical process equipment

\section{HIGH VALUE PROPERTY}

A single ISC with CCC is valued at approximately $\$ 350,000$ The cost of the RadVault $^{\mathrm{M} M}$ including the sIX NRF TRIGA ${ }^{\oplus}$ casks and two DOT-6M containers is approxımately $\$ 300,000$ The estımated cost of an ISO container with NAC-1 cask and inner canister is $\$ 250,000$ The value of the spent fuel contained within these varıous dry cask storage systems has not been determıned There are no single pleces of equipment valued in excess of $\$ 1 \mathrm{M}$ 


\section{DAMAGE POTENTIAL}

Since there are no fire suppression systems associated with the ISA facilty, the Maxımum Credıble Fire Loss equals the Maxımum Possible Fire Loss The cost of a single ISC with a Core Component Container (CCC) is approximately $\$ 350,000$ The cost for a Rad-Vault ${ }^{\mathrm{TM}}$ including the sIX NRF TRIGA casks and two DOT-6M containers is approximately $\$ 300,000$ The estımated cost of an ISO contaner with NAC-1 cask and inner canister is $\$ 250,000$ The damage potential associated with a fire that is bounded by the 10 CFR thermal analysis test in unknown There will not be a radioactive material release in excess of the established guidelines so cleanup costs are not a consideration However the cask could be damaged to the degree that entire replacement is necessary The cask for each storage system would be a fraction of the each of the above approximated storage system costs There is also the possibility that the casks could be inspected and recertified following a fire The costs associated with inspection and recertification of an ISC, Rad-Vault ${ }^{\mathrm{TM}}$ or NAC-1 cask is estımated to be $\$ 100,000$ No fire protection systems are required based on this fire loss estımate

\section{FIRE DEPARTMENT RESPONSE}

Due to the absence of any fire detection and alarm system at the 200 Area ISA, personnel action is required to notify the Hanford Fire Department (HFD) in the event of a fire The HFD response time from the 200 Area Fire Station is approximately 5 minutes Vehicle access is provided to the 200 Area ISA via a paved road and compacted gravel The HFD is fully staffed, trained and equipped No Fire Brigade is planned for this facility A prefire plan has not been generated, but is required prior to ISA facility operation

\section{RECOVERY POTENTIAL}

Damage significant enough to require an ISC, Rad-Vault ${ }^{\mathrm{TM}}$, or NAC-1 cask to be taken out of service is not anticipated due to the design of the dry cask storage systems and limited fire fuel loading If any of the dry cask storage systems is ever exposed to a fire, It will be inspected and will require recertification from a qualified testing agency

\section{POTENTIAL FOR A TOXILOGICAL, BIOLOGICAL ANDIOR RADIOLOGICAL INCIDENT DUE TO A FIRE}

No toxicological or biological consequences from a fire are antıcipated A radiological release, other than noble gases, is possible if an ISC, Rad-Vault ${ }^{\mathrm{M}}$ containing NRF TRIGA ${ }^{\infty}$ casks and DOT-6M contanners or NAC-1 cask withın an ISO container were exposed to a fire that exceeds the 10 CFR 7173 thermal test criteria 


\section{EMERGENCY PLANNING}

Emergency plannıng for the 200 Area ISA will be addressed in emergency planning documentation for the Canıster Storage Bulding

\section{SECURITY AND SAFEGUARDS CONSIDERATIONS RELATED TO FIRE PROTECTION}

There are no security and safeguards consideration related to fire protection at the 200 Area ISA The 200 Area ISA is readily accessible to the HFD The HFD can easily access any emergency within the 200 Area ISA

\section{NATURAL HAZARDS IMPACT ON FIRE SAFETY}

No adverse impact to fire safety is foreseen as a result of floods, wind, or earthquakes The dry cask storage systems have been analyzed to withstand 200 Area natural phenomena hazards

\section{EXPOSURE FIRE POTENTIALS, INCLUDING THE POTENTIAL FIRE SPREAD BETWEEN FIRE AREAS}

The 200 Area ISA is located approximately 200 feet west of the Canıster Storage Building and 60 feet south of MO-723 The nearest dry cask storage system to the CSB is the ISC, approximately 260 feet away The nearest DCSS to MO-723 is the NAC-1 cask, approxımately 200 feet away An equipment storage buildıng may be constructed along the east fence line of the 200 Area ISA to house various equipment associated with the dry cask storage systems The equipment is primarily lifting fixtures, impact Iımiters, tools, and a transfer cask, which are non-combustible The nearest dry cask storage system to the proposed storage building is the ISCs, approximately 80 feet away No exposure fire threat is posed to or by these buildings due to the separation distance between these buldings and the dry cask storage systems withın the 200 Area ISA Separations distances meet or exceed the criteria established in National Fire Protection Association (NFPA) 80A, Extenor Fire Exposures A fire involving natural vegetation is not considered an event that will threaten the integrity of the dry cask storage systems However, the accumulation of natural vegetation in and around the ISA facility still represents a hazard that should be addressed 


\section{RECOMMENDATIONS}

1 The fuel truck is not permitted inside the ISA perımeter fencing Refueling operations involving the transporter tractor truck, the crane and any other vehicles must take place outside the ISA perımeter fencing

2 Develop an admınıstratıve procedure or other appropriate documented method to prohibit the storage of all combustible materials within the ISA facility and control the quantity, use, cleanup and removal of combustıble materials needed for maintenance and operational purposes, including plywood The admınıstratıve procedure should also address routıne housekeeping within the ISA facility and a means to control natural vegetation, which could include removal and/or herbicide spraying

3 Provide a means to ensure at least one access gate on each end of the ISA facility (2 total), are unlocked when the facility is occupied in order to facilitate egress in the event of an emergency

4 Some form of two-way communication should be in place during activities inside the ISA facility

5 A prefire plan must be developed by the HFD prior to any dry cask storage systems being placed in the ISA 


\section{REFERENCES}

10 CFR 71, January 1999, Packaging and Transportation of Radioactive Material, Code of Federal Regulations, as revised

GA 1995 Document No 910683, FFTF Spent Fuel Interım Storage Cask Desıgn Analysis Report, Revision A, General Atomics, San Diego, California, September 1995

NAC 1990, Safety Analysis Report for the NFS-4/NAC-1 Spent-Fuel Shipping Cask, Nuclear Assurance Corporation, Norcross, Georgia, March 1990

TRI 1996, Letter TRI-RDC-96-101, R D Carrell to C T Sadanaga, "FFTF Appendix H Fire Accident Evaluation for 300 Area LWR Fuel", Technical Resources International, Rıchland, Washıngton, May 1996

WHC 1995, ECN 189864 to WHC-TI-75002, Fast Flux Test Facility Final Safety Analysis Report, Amendment 75, Westinghouse Hanford Company, Richland, Washington, December 1995

WHC 1996, ECN 631821, WHC-SD-FF-FHA-001, Rev 0-E, Fire Hazards Analysis for the Fast Flux Test Facility, Westınghouse Hanford Company, Richland, Washington, June 1996

Babrauskas, V, "Burnıng Rates", Section 2/Chapter 1 of SFPE Handbook of Fire Protection Engineering, Dinenno, P D et al, Eds, Natıonal Fire Protection Association, 1993 